\title{
BURIALS FROM CEMETERY WAD BEN NAGA C260 - FIRST REPORT
}

\author{
Gabriela Jungová ${ }^{1}$
}

\begin{abstract}
During the sixteenth-eighteenth excavation seasons, cemetery WBN C260 at the archaeological site of Wad Ben Naga (Sudan) yielded the remains of fourteen individuals, both adult and non-adult. The burials, tentatively dated as post-Meroitic/ Christian, were oriented to the north or north-west, with scarce grave goods, simple substructures, and no identified superstructures. Anthropological analysis revealed non-specific signs of stress including porotic hyperostosis and cribra orbitalia, linear enamel hypoplasia, and endocranial lesions known as serpens endocrania symmetrica.
\end{abstract}

KEYWORDS: Wad Ben Naga - post-Meroitic cemetery - Christian cemetery - grave goods - bioarchaeology - palaeopathology

\section{Introduction}

Cemetery WBN C260 [Fig. 1] is located in the central part of the archaeological site of Wad Ben Naga in present-day Sudan. The contemporary village of Wad Ben Naga lies in direct proximity to the ruins of a Meroitic royal city that features a royal palace ascribed to Queen Amanishakheto (WBN 100), multiple temples, and several profane structures. The ancient settlement was gradually partially covered by interments of Meroitic and later archaeological contexts. The burial ground WBN C260 was discovered after geomagnetic survey from $2017^{2}$ had revealed the existence of a previously unknown structure. Subsequent excavations uncovered remains of kiosk WBN 390 dated to the $1^{\text {st }}$ century $\mathrm{CE}^{3}$ The kiosk was surrounded by numerous pits and depressions of varying dimensions and shapes, mostly artificial; a smaller number of pits was found in the interior of the structure. Some of the depressions turned to be burial pits of adults as well as nonadults. In the following excavation seasons, the uncovered area was extended in search for the full extension of the cemetery that was numbered WBN C260. ${ }^{4}$ The boundary has been presumably reached in the north and east of the cemetery; south-western extension is yet to be explored. So far fourteen individuals in thirteen graves have been excavated. One grave contained two individuals, a mother and a foetus.

1 Contact: Gabriela Jungová, National Museum - Náprstek Museum of Asian, African and American Cultures, Prague, Czech Republic; e-mail: gabriela_jungova@nm.cz. The article was written within the framework of the project 'The Building Program of King Natakamani and Queen Amanitore' supported by the Czech Science Foundation (grant no. 18-00454S). The present author wishes to express her sincerest thanks to Pavel Onderka, the head of the Archaeological Expedition to Wad Ben Naga, and to the National Corporation for Antiquities and Museums, namely to Dr. Abdel-Rahman Ali Mohamed and Juweriya Osman Mohamed Zain.

2 Ullrich et al. 2018.

3 Onderka et al. 2019a.

4 Onderka et al. 2019b.

This work is licensed under the Creative Commons Attribution-Noncommercial-No Devivs 3.0 License 


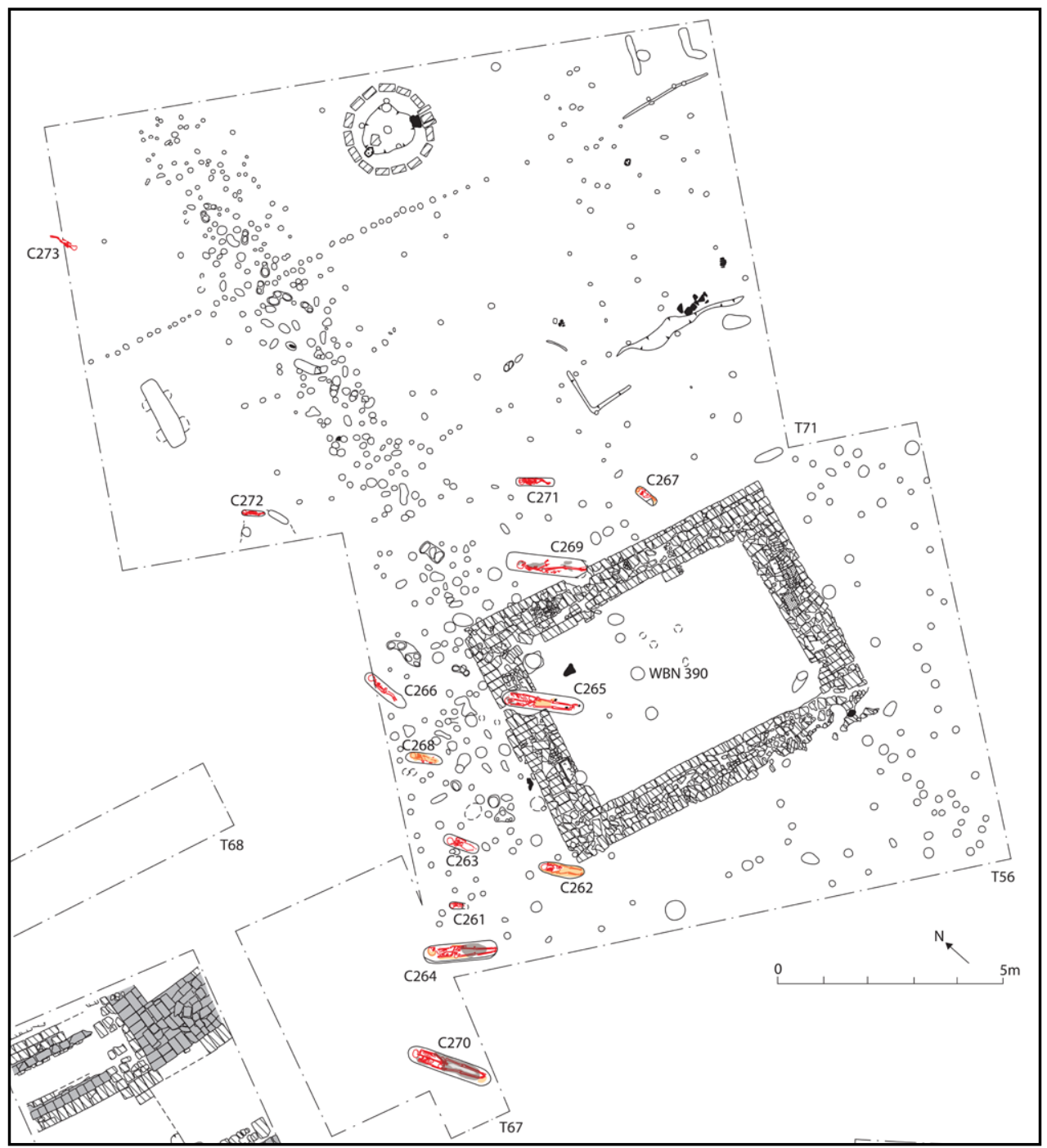

Fig. 1. Cemetery WBN C260 (Illustration: Gabriela Jungová, Pavel Onderka, Vlastimil Vrtal).

\section{Orientation}

Cemetery WBN C260 differs from all other hitherto excavated burial grounds at Wad Ben Naga in the orientation of graves. All of the documented interments from cemeteries WBN C100, ${ }^{5}$ WBN C200, ${ }^{6}$ and WBN C2207, or burials deposited in the ruins of the Typhonium (WBN 200) ${ }^{8}$ and the Eastern Temple (WBN 500) ${ }^{9}$ were oriented with head

5 Onderka 2012, pp. 132-133; Onderka et al. 2018b, pp. 143-144.

6 Onderka et al. 2015, pp. 101-102; Onderka et al. 2016, p. 111; Onderka et al. 2018a, pp. 103-104.

7 Onderka et al. 2018b, pp. 138-140.

8 Onderka 2012, p. 132; Onderka et al. 2013, p. 7.

9 Jungová 2019. 
to south, south-east, south-west (exceptionally), and east. ${ }^{10}$ In contrast, burials in cemetery WBN C260 were oriented approximately along the north-south axis, with head to north (8 cases) or north-west (4 cases). Two exceptions to this pattern were individuals $\mathrm{C} 269 \mathrm{~b}$, a foetus that was expulsed post mortally and hence its position is independent of the burial rite, and C273 that is most likely an intrusive burial of a slightly later date and will be discussed separately.

\section{Funeral rite}

Graves were cut in the local sāra bedrock that is crumbly and heterogenous. Exact delimitation of the individual burial pits was hence challenging in some cases, but the construction of the graves was fairly simple. No shafts or side niches were present; the depth of the pits varied between 28 and $75 \mathrm{~cm}$, the mean being $48 \mathrm{~cm}$. In burial WBN C273, no pit was identified (see below). The graves were filled with soil with occasional pebbles and small stones - a mixture that in no way differed from the surroundings. No superstructures or deposits of material that could have once constructed them were identified.

Body position in the grave varied [Tab. 1]. Excluding burial WBN C273, six individuals were interred in a semi-flexed position, three on the left side, two on the right side, and one in a prone position, i.e. on the belly. Further six individuals were buried in an extended position; four of them were supine (on their back), two on their left side. As can be seen, the body positioning was distributed fairly equally, albeit with a slight preference for the left side over the right.

Position of arms and hands also varied. Five individuals had their arms semi-flexed with hands placed in the pelvic area, in front of it, or under it, depending on their supine or lateral respective positions. Three individuals had one arm extended and the other arm semi-flexed over the pelvic area. Left arm was bent in one case, right arm in two cases; out of these, the left hand was under the pelvis in one case. Two individuals had their right arm flexed over the chest, while the left arm was extended. One individual was arranged with both arms extended and one with both arms flexed in front of the chest. Body position of individual C269b is again irrelevant for the study of the funeral rite.

In eight graves, remains of textile and/or mat covering the body were found; in one additional grave, no textile was retrieved but impressions on the bones clearly indicated its former presence. The individuals were apparently completely wrapped in multiple layers of textile and then in one or two layers of a mat [Pl. 1]. In three graves, no textile and/or mat remnants were identified, which, as illustrated by the above-mentioned case, does not necessarily prove their absence in the past. The use of body wrappings was most likely not dependent on the age of the deceased, as their presence is attested both among the adults (four cases) as well as the non-adults (five cases). No indication of a coffin or a bed was found in any of the graves.

Burial goods were rather scarce and only identified in three graves. Two cowry shells were placed on top of non-adult individual C262's head. The burial of adult C264 featured a cowry shell at the head and a mollusc shell at the feet. The last case was nonadult C271 in whose grave were retrieved eleven ostrich-eggshell disc beads, 5-8 mm

10 For a general overview of the cemeteries see Onderka 2016, pp. 41-49. 
in diameter (SM19/131). Based on their position, they originally most likely formed a necklace [Pl. 2].

Tab. 1. Summary of funerary characteristics of the individuals interred in cemetery WBN C260.

\begin{tabular}{|c|c|c|c|c|c|c|}
\hline $\begin{array}{l}\text { Ind. } \\
\text { No. }\end{array}$ & Orientation & Side & $\begin{array}{l}\text { Body } \\
\text { position }\end{array}$ & Arms position & Textile & Burial goods \\
\hline C261 & $\begin{array}{l}\text { head to NW, } \\
\text { face to } \mathrm{E}\end{array}$ & left & semi-flexed & flexed & & \\
\hline C262 & $\begin{array}{l}\text { head to } N \text {, } \\
\text { face to } \mathrm{E}\end{array}$ & supine & extended & $\begin{array}{l}\mathrm{R} \text { semi-flexed on pelvis, } \mathrm{L} \\
\text { under pelvis }\end{array}$ & present & cowry shells \\
\hline C263 & $\begin{array}{l}\text { head to } N \text {, } \\
\text { face to } \mathrm{E}\end{array}$ & supine & extended & $\begin{array}{l}\mathrm{R} \text { flexed on chest, } \mathrm{L} \\
\text { extended }\end{array}$ & & \\
\hline C264 & $\begin{array}{l}\text { head to NW, } \\
\text { face to NE }\end{array}$ & left & extended & $\begin{array}{l}\text { R semi-flexed on pelvis, } \mathrm{L} \\
\text { extended }\end{array}$ & present & $\begin{array}{l}\text { cowry shell, } \\
\text { mollusc shell }\end{array}$ \\
\hline C265 & $\begin{array}{l}\text { head to } N \text {, } \\
\text { face } W\end{array}$ & supine & extended & semi-flexed, hands in lap & present & \\
\hline C266 & $\begin{array}{l}\text { head to N, } \\
\text { face to } \mathrm{E}\end{array}$ & left & semi-flexed & extended & impressions & \\
\hline C267 & $\begin{array}{l}\text { head to } N \text {, } \\
\text { face to } \mathrm{E}\end{array}$ & left & semi-flexed & $\begin{array}{l}\text { semi-flexed, hands in } \\
\text { front of lap }\end{array}$ & present & \\
\hline C268 & $\begin{array}{l}\text { head to } \mathrm{N}, \\
\text { face to } \mathrm{W}\end{array}$ & right & semi-flexed & $\begin{array}{l}\mathrm{R} \text { flexed under body, } \mathrm{L} \\
\text { extended }\end{array}$ & present & \\
\hline $\mathrm{C} 269 \mathrm{a}^{*}$ & $\begin{array}{l}\text { head to } N \text {, } \\
\text { face to } E\end{array}$ & left & extended & $\begin{array}{l}\text { semi-flexed, hands in } \\
\text { front of lap }\end{array}$ & present & \\
\hline $\mathrm{C} 270$ & $\begin{array}{l}\text { head to } N \text {, } \\
\text { face to } \mathrm{E}\end{array}$ & supine & extended & $\mathrm{R}$ along body, $\mathrm{L}$ in lap & present & \\
\hline C271 & $\begin{array}{l}\text { head to NW, } \\
\text { face up }\end{array}$ & prone & semi-flexed & $\begin{array}{l}\text { semi-flexed in lap under } \\
\text { body }\end{array}$ & present & eggshell beads \\
\hline $\mathrm{C} 272$ & $\begin{array}{l}\text { head to NW, } \\
\text { face to SW }\end{array}$ & right & semi-flexed & $\begin{array}{l}\text { semi-flexed, hands in } \\
\text { front of lap }\end{array}$ & & \\
\hline
\end{tabular}

* Individual C269b (foetus) is omitted as the burial features are either irrelevant or identical to individual C269a.

\section{Anthropological analysis}

Anthropological analysis of the remains included the estimation of age ${ }^{11}$ and, in the case of adults, sex ${ }^{12}$, standard measurements of long bones, and the assessment of pathological conditions and non-metric traits. Estimation of sex was not attempted in the non-adults. Maximum length of the femora is presented [Tab. 2] to allow comparison with other skeletal populations without any bias due to different methods of stature estimation in adults ${ }^{13}$ and non-adults ${ }^{14}$.

11 Brooks and Suchey 1990; Buckberry and Chamberlain 2002; Maresh 1970.

12 Bruzek 2002; Buikstra and Ubelaker 1994, pp. 16-21.

13 Raxter et al. 2008; Sjøvold 1990; Trotter and Gleser 1952; Trotter and Gleser 1958.

14 Feldesman 1992; Ruff 2007. 
The studied individuals included four adults, three females and one male. All females died younger than the male, but the sample is too small to draw any conclusions on the demography. Nine individuals were non-adults. The oldest one died aged 4-5.5 years, most of them, however, did not live past 3 years of age. The foetus found together with the mother was $32 \pm 2$ weeks old.

Two of the four adults showed bilateral septal aperture in the humerus. This condition of unknown aetiology ${ }^{15}$ can be relatively frequently found in ancient Nubian populations $^{16}$ including individuals from other cemeteries of Wad Ben Naga ${ }^{17}$. One of the two individuals, female C264, also showed degenerative changes on the joint facet of the trochlear notch in both ulnae. Defect in fusion of several posterior vertebral elements in the sacrum resulted in spina bifida occulta; the sacrum consists of six segments [Pl. 3]. The other individual, female C265, showed a drop-shaped foramen in the right scapular insfraspinous fossa [Pl. 4]. This defect most likely resulted from a failure in ossification during foetal development. ${ }^{18}$ Although this finding may be associated with physical weakness of the individual, ${ }^{19}$ it is rather unlikely in this particular case where the female was one of a rather robust stature [see Tab. 2].

The only adult male (C270) suffered from symphalangism, i.e. fusion of interphalangeal joints in one ray of his right hand. This would result into stiffness and immobility of the finger, which was, however, apparently not very limiting as he lived well past 40 years of age. In addition, porotic hyperostosis and cribra orbitalia were identified. Both types of lesions were inactive and partially healed. These defects were previously mostly associated with iron-deficiency anaemia, but recent studies link them to other possible causes including congenital types of anaemia and inflammations. ${ }^{20}$ At this point of research, the lesions only indicate the presence of non-specific biological stressor/s.

Dental pathologies were only found in two cases, both adults. Individual C264, an adult female, showed complete agenesis in the maxillar left third molar, and microdontia of the right third molar resulting in a peg-shaped tooth. Other teeth including both mandibular third molars were fully erupted. Mild gingivitis could be ascertained. Individual C269a, a young adult female, showed linear enamel hypoplasia (LEH) in frontal teeth. This defect in enamel mineralization is associated with stress in early childhood, while the teeth crowns were still forming. ${ }^{21}$

Individual C271, non-adult, displays serpens endocrania symmetrica (SES), or maze-like branching lesions, on the endocranial plate [Pl. 5]. These lesions are associated with two major causes: infections of the upper and lower respiratory tracts, and meningeal haemorrhage, whether traumatic, caused by infections, or nutritional deficiencies. ${ }^{22}$ All of these conditions are common and potentially lethal to children, and so it may be speculated that the occurrence of SES in this individual may be linked to the direct cause of death.

15 Mann and Hunt 2012, p. 126.

16 See e.g. Judd 2008, p. 93, Table 8.12; Judd 2012, p. 188; Lebedev and Reshetova 2017, p. 184, Table 3.

17 Unpublished data.

18 Barnes 2012, p. 128; Pate et al. 1985, p. 275.

19 Čihák 2011, p. 245.

20 Brickley 2018; Walker et al. 2009; Wapler et al. 2004; although cf. Oxenham - Cavill 2010.

21 Larsen 2016, p. 44-48; Mann and Hunt 2012, p. 30-33.

22 Hershkovitz et al. 2002; Lewis 2004. 


\section{Intrusive burial C273}

Individual C273's interment deviates from the other burials of cemetery WBN C260 in the orientation (head to south-east), the absence of a clearly distinguishable burial pit and more shallow position relative to the other burials: while graves WBN C261-C272 were all cut several decimetres deep into sāra, WBN C273 was laid on its surface. It was concluded that this burial is an intrusion from a different archaeological context and was, therefore, excluded from the analysis. Due to very poor preservation, the remains were documented, covered with geotextile and reburied, without actual retrieval.

Tab 2. Summary of anthropological examinations of the individuals from cemetery WBN C260.

\begin{tabular}{|l|l|l|l|l|l|l|l|}
\hline $\begin{array}{l}\text { Ind. } \\
\text { No. }\end{array}$ & Sex & Age category * & Age & $\begin{array}{l}\text { Fe right } \\
(\mathbf{m m})\end{array}$ & $\begin{array}{l}\text { Fe left } \\
(\mathbf{m m})\end{array}$ & $\begin{array}{l}\text { Pathological } \\
\text { observations }\end{array}$ & $\begin{array}{l}\text { Non-metric } \\
\text { traits }\end{array}$ \\
\hline C261 & indet. & infant & $12-24 \mathrm{~m}$. & $\mathrm{n} / \mathrm{a}$ & $\mathrm{n} / \mathrm{a}$ & & \\
\hline C262 & indet. & early childhood & $4-5.5 \mathrm{y}$. & 226.0 & 226.0 & & \\
\hline C263 & indet. & toddler & $12-18 \mathrm{~m}$. & 131.0 & 131.0 & & joint degeneration, \\
\hline C264 & female & adult & $30+\mathrm{y}$. & 415.0 & $\mathrm{n} / \mathrm{a}$ SA bifida occulta & SA, scapular \\
\hline C265 & female & adult & $30+\mathrm{y}$. & 453.5 & 451.5 & & foramen \\
\hline C266 & indet. & early childhood & $3 \pm 1 \mathrm{y}$. & 187.0 & 186.0 & & \\
\hline C267 & indet. & toddler & $6-12 \mathrm{~m}$. & 120.0 & 121.0 & & \\
\hline C268 & indet. & neonate & $<6 \mathrm{~m}$. & $\mathrm{n} / \mathrm{a}$ & 87.0 & & \\
\hline C269a & female & adult & $18-20 \mathrm{y}$. & 429.0 & 427.0 & LEH & \\
\hline C269b & indet. & foetus & $32 \pm 2$ preg. w. & 57.0 & 57.5 & & \\
\hline C270 & male & adult & $40+\mathrm{y}$. & $\mathrm{n} / \mathrm{a}$ & 450.0 & $\begin{array}{l}\text { symphalangism, } \\
\text { PH, CO }\end{array}$ & \\
\hline C271 & indet. & toddler & $18-30 \mathrm{~m}$. & 163.0 & 163.0 & SES & \\
\hline C272 & indet. & toddler & $9-15 \mathrm{~m}$. & 129.0 & 127.0 & & \\
\hline
\end{tabular}

* Non-adult categories after Judd 2012, pp. 17-19, Table 3.3

$\mathrm{CO}=$ cribra orbitalia, indet. = indeterminate, $\mathrm{LEH}=$ linear enamel hypoplasia, $\mathrm{PH}=$ porotic hyperostosis, $\mathrm{SA}=$ septal aperture, $\mathrm{SES}=$ serpen s endocrania symmetrica

\section{Discussion}

Some of the graves were partially cut into the walls of kiosk WBN 390, but they do not interfere with each other. This implies that the ruins were not distinguishable when the ground was used as a cemetery, but the individual graves may have been marked on the surface in some way. The kiosk dated to the $1^{\text {st }}$ century CE hence so far provides the only relative chronology for cemetery WBN C260 that clearly postdates it. The burial ground may at this point be broadly set to the post-Meroitic or Christian periods.

No signs of superstructures or outer delimitations of the graves were identified; they may have not been built at all, or they were of perishable nature and disappeared in the course of time. A possible circumstance for the latter option is annual flooding of the area of the cemetery. None of the burials yielded any signs of disturbance, so we can conclude that the low frequency of burial goods was not due to looting, but due to their original scarce employment. 
Cemetery WBN C260 somewhat contrasts with many post-Meroitic cemeteries that commonly feature superstructures, elongated shafts with burial chambers, burial goods including pottery, and the deceased in a contracted position with head to the south. The absence of a superstructure ${ }^{23}$ or the orientation to the north or north-west ${ }^{24}$ are not unheard of, though, and neither are the other above-mentioned discrepancies. It should be considered that most of the studied and published cemeteries were identified as such precisely because of the presence of a superstructure, which itself may then be linked to the design of the substructure, the burial position and/or the presence of the burial goods. Burials from the Christian period are typically associated with east-west orientation, ${ }^{25}$ but, bearing in mind that dating to the Christian period does not necessarily mean that the studied individuals were in fact Christian by religion, ${ }^{26}$ this option cannot be entirely ruled out at this moment.

Cemetery WBN C260 thus brings an invaluable view into the diversity of the ancient Nubian burial traditions. It is noteworthy that both non-adults and adults, both male and females, are interred in a similar manner which suggests a shared burial practice regardless of age or sex within the group. This does not, of course, exclude the possibility that the burial ground is delimited in another way based on yet unidentified criteria. For instance, cemetery WBN C260 lies in direct proximity to cemetery WBN C200. Cemetery WBN C200 is dated to the $4^{\text {th }}$ century $\mathrm{CE}^{27}$ and its interments display a markedly different funeral rite. ${ }^{28}$ This may reflect chronological, socio-economic, ethnic, health, or other differences.

The skeletal sample is too small for any definite conclusions on the population structure and health status, but two points can be made. First, a relatively large proportion of non-adults under 5 years of age is remarkable both for their excellent preservation and as a testimony of their social status. Second, identified pathologies include porotic hyperostosis, cribra orbitalia, linear enamel hypoplasia, and endocranial lesions (SES). All of these are recognized as manifestations of biological stress, whether caused by nutritional deficiencies, infections, or diseases. In some cases (mainly in individual C271), the stressors may be directly associated with the cause of death.

\section{Conclusion}

Cemetery WBN C260 so far yielded fourteen individuals in thirteen graves. Twelve burials are relatively dated as post-Meroitic or Christian, one as a slightly later intrusion. The individuals were interred with their head to north or north-west with minimal burial goods; the graves show no visible superstructures. Anthropological analysis revealed the presence of non-specific biological stressors in several cases.

Definite conclusions on the population in question cannot be drawn until the full extension will have been explored. Yet, cemetery WBN C260 already broadens our knowledge on ancient Nubian burial customs and health status.

23 Cf. Edwards 1989, p. 167; Judd 2012, p. 79; Lebedev and Reshetova 2017, p. 166-167.

24 See e.g. Judd 2012, p. 80; Mohamed Faroug 2006.

25 Welsby 2002, p. 48.

26 As discussed e.g. by Judd 2012, p. 82; Crawford and Addison 1951, pp. 11, 108.

27 Onderka 2016, p. 46.

28 Onderka et al. 2015, pp. 101-102; Onderka et al. 2016, p. 111; Onderka et al. 2018a, pp. 103-104. 


\section{Literature:}

Barnes, E. (2012). Atlas of developmental field anomalies of the human skeleton. A paleopathology perspective. Hoboken: Wiley-Blackwell.

Brickley, M. (2018). Cribra orbitalia and porotic hyperostosis: a biological approach to diagnosis. American Journal of Physical Anthropology, 167(4), pp. 896-902.

Brooks, S. and Suchey, J. (1990). Skeletal age determination based on the os pubis: a comparison of the Acsádi-Nemeskéri and Suchey-Brooks methods. Human Evolution, 5, pp. 227-238.

Bruzek, J. (2002). A method for visual determination of sex, using the human hip bone. American Journal of Physical Anthropology, 117(2), pp. 157-168.

Buckberry, J. and Chamberlain, A. (2002). Age estimation from the auricular surface of the ilium: a revised method. American Journal of Physical Anthropology, 119, pp. 231-239.

Buikstra, J. and Ubelaker, D. (1994). Standards for data collection from human skeletal remains. Arkansas Archaeological Survey Research Series No. 44. Fayetteville: Arkansas Archeological Survey.

Crawford, O. G. S. and Addison, F. (1951). Abu Geili and Saqadi E Dar el Mek. Oxford: Oxford University Press.

Čihák, R. (2011). Anatomie 1. $3^{\text {rd }}$ ed. Praha: Grada.

Edwards, D. (1989). Archaeology and settlement in Upper Nubia in the $1^{\text {st }}$ millennium A.D. Cambridge monographs in African archaeology 36. BAR International Series 537. Oxford: Sudan Archaeological Research Society.

Feldesman, M. (1992). Femur/stature ration and estimates of stature in children. American Journal of Physical Anthropology, 87, pp. 447-459.

Hershkovitz, I., Greenwald, C., Latimer, B., Jellema, L., Wish-Baratz, S., Eshed, V., Dutour, O. and Rothschild, B. (2002). Serpens endocrania symmetrica (SES): a new term and a possible clue for identifying intrathoracic disease in skeletal populations. American Journal of Physical Anthropology, 118, pp. 201-216.

Judd, M. (2008). The human skeletal analysis. In: S. Salvatori and D. Usai, eds., A Neolithic cemetery in the Northern Dongola reach. Excavations at site R12. Sudan Archaeological Research Society Publication Number 16. BAR International Series 1814. Oxford: Archaeopress, pp. 83-104.

Judd, M. (2012). Gabati. A Meroitic, post-Meroitic and medieval cemetery in Central Sudan. Vol. 2, the physical anthropology. Sudan Archaeological Research Society Publication Number 20. BAR International Series 2442. Oxford: Archaeopress.

Jungová, G. (2019). Human Burial in WBN 501. In: P. Onderka et al., Wad Ben Naga Report II: The Eastern and Small Temples, Prague: Národní muzeum, pp. 131-132.

Larsen, C. (2015). Bioarchaeology. Interpreting behaviour from the human skeleton. $2^{\text {nd }}$ ed. Cambridge: Cambridge University Press. 
Lebedev, M. and Reshetova, I. (2017). Cutting graves in ancient ruins. The medieval cemetery at Abu Erteila (seasons 2012-2015). Beiträge zur Sudanforschung, 12, pp. 165-191.

Lewis, M. (2004). Endocranial lesions in non-adult skeletons: understanding their aetiology. International Journal of Osteoarchaeology, 14, pp. 82-97.

Maresh, M. (1970). Measurements from roentgenograms, heart size, long bone lengths, bone, muscles and fat widths, skeletal maturation. In: R. McCammon, ed., Human growth and development. Springfield: Thomas, pp. 157-200.

Mann, R. and Hunt, D. (2012). Photographic regional atlas of bone disease. Springfield: Charles C. Thomas Publisher, Ltd.

Mohamed Faroug Abd el-Rahman (2006). Gheresli: a post-Meroitic activity centre in the Blue Nile region. Sudan \& Nubia, 10, pp. 104-109.

Onderka, P. (2012). Preliminary report on the third excavation season of the Archaeological Expedition to Wad Ben Naga. Annals of the Náprstek Museum, 33, pp. 117-134.

Onderka, P. (2016). Wad Ben Naga Report I: An introduction to the site. Prague: Národní muzeum.

Onderka, P., Vrtal, V. et al. (2013). Preliminary report on the fifth excavation season of the Archaeological Expedition to Wad Ben Naga. Annals of the Náprstek Museum, 34(2), pp. 3-18.

Onderka, P., Vrtal, V. and Gatzsche, A. (2015). Preliminary report on the ninth excavation season of the Archaeological Expedition to Wad Ben Naga. Annals of the Náprstek Museum, 36(2), pp. 93-110.

Onderka, P., Vrtal, V. and Gatzsche, A. (2016). Preliminary report on the tenth excavation season of the Archaeological Expedition to Wad Ben Naga. Annals of the Náprstek Museum, 37(1), pp. 103-116.

Onderka, P., Vrtal, V. and Gatzsche, A. (2018a). Preliminary report on the fourteenth excavation season of the Archaeological Expedition to Wad Ben Naga. Annals of the Náprstek Museum, 39(1), pp. 95-108.

Onderka, P., Vrtal, V. and Honzl, J. (2019a). Preliminary report on the sixteenth excavation season of the Archaeological Expedition to Wad Ben Naga. Annals of the Náprstek Museum, 40(1), pp. 133-147.

Onderka, P., Vrtal, V. and Jungová, G. (2018b). Preliminary report on the fifteenth excavation season of the Archaeological Expedition to Wad Ben Naga. Annals of the Náprstek Museum, 39(2), pp. 137-148.

Onderka, P., Vrtal, V. and Jungová, G. (2019b). Preliminary report on the seventeenth excavation season of the Archaeological Expedition to Wad Ben Naga. Annals of the Náprstek Museum, 40(2), pp. 107-120.

Oxenham, M. and Cavill, I. (2010). Porotic hyperostosis and cribra orbitalia: the erythropoietic response to iron-deficiency anaemia. Anthropological Science, 118(3), pp. 199200. 
Pate, D., Kursunoglu M., Resnick, D. and Resnik. C. (1985). Scapular foramina. Skeletal radiology, 14, pp. 270-275.

Raxter, M., Ruff, C., Azab, A., Erfan, M., Soliman, M. and El-Sawaf A. (2008). Stature estimation in ancient Egyptians: a new technique based on anatomical reconstruction of stature. American Journal of Physical Anthropology, 136, pp. 147-155.

Ruff, C. (2007). Body size prediction from juvenile skeletal remains. American Journal of Physical Anthropology, 133, pp. 698-716.

Salah Mohamed Ahmed. (2011). A short "training campaign" at Abu Erteila. 7-27 December 2003. In: V. Rondot, F. Alpi and F. Villeneuve, eds., La pioche et la plume. Paris: Presses de l'université Sorbonne, pp. 297-301.

Sjøvold, T. (1990). Estimation of stature from long bones utilizing the line of organic correlation. Human Evolution, 5, pp. 431-447.

Trotter, M. and Gleser, G. (1952). Estimation of stature from long bones of American whites and Negroes. American Journal of Physical Anthropology, 10, pp. 463-514.

Trotter, M. and Gleser, G. (1958). A re-evaluation of estimation of stature based on measurements of stature taken during life and of long bones after death. American Journal of Physical Anthropology, 16, pp. 79-123.

Ullrich, B., Onderka, P. and Vrtal, V. (2018). Preliminary report on the geophysical survey of Central Wad Ben Naga. Annals of the Náprstek Museum, 39(2), pp. 119-136.

Walker, P., Bathurst, R., Richman, R., Gjerdrum, T. and Andrushko, V. (2009). The causes of porotic hyperostosis and cribra orbitalia: a reappraisal of the iron-deficiency-anemia hypothesis. American Journal of Physical Anthropology, 189, pp. 109-125.

Wapler, U., Crubézy, E. and Schultz, M. (2004). Is cribra orbitalia synonymous with anemia? Analysis and interpretation of cranial pathology in Sudan. American Journal of Physical Anthropology, 123, pp. 333-339.

Welsby, D. (2002). The Medieval Kingdoms of Nubia. London: British Museum Press. 


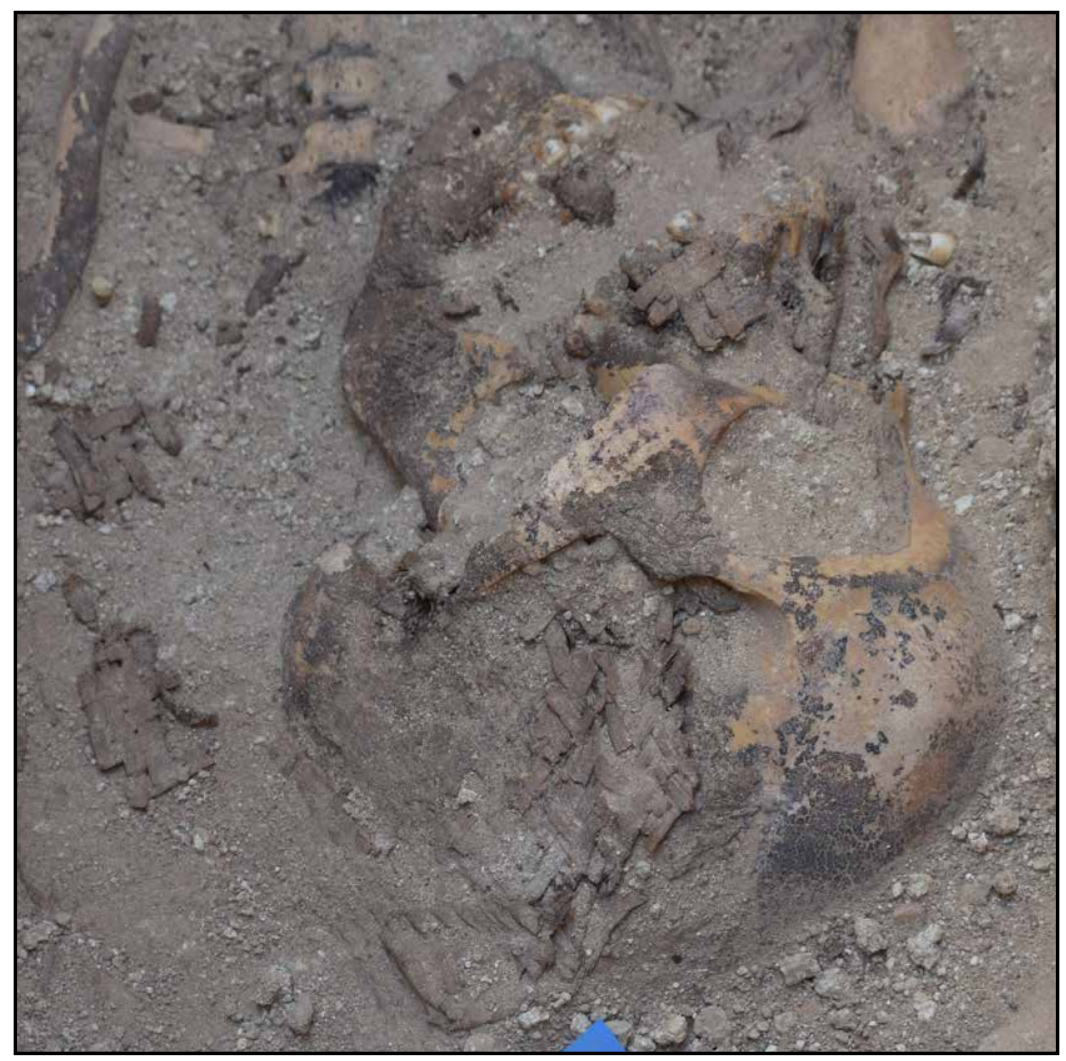

Pl. 1. Preserved remains of textile (over the jaw) and mat in burial WBN C265 (Photo: Gabriela Jungová).

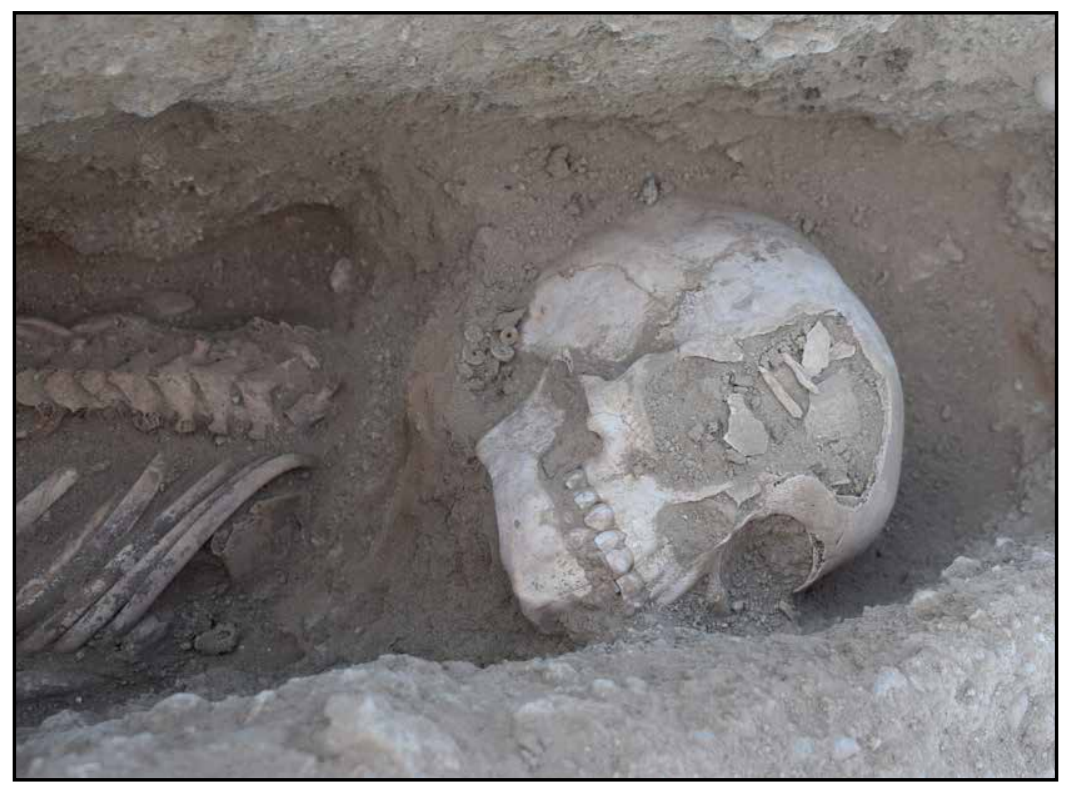

Pl. 2. Ostrich-eggshell beads in burial WBN C271 (Photo: Gabriela Jungová). 


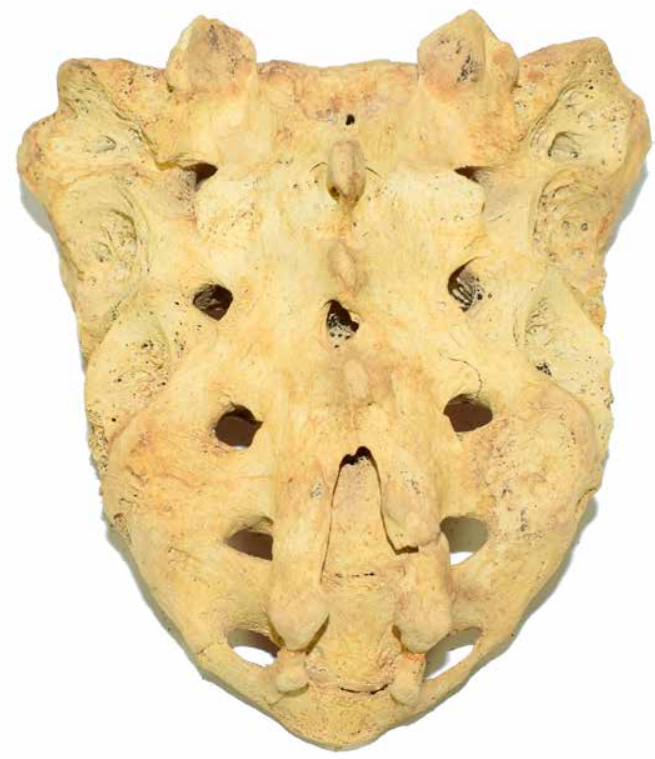

Pl. 3. Spina bifida occulta, individual C264 (Photo: Gabriela Jungová).

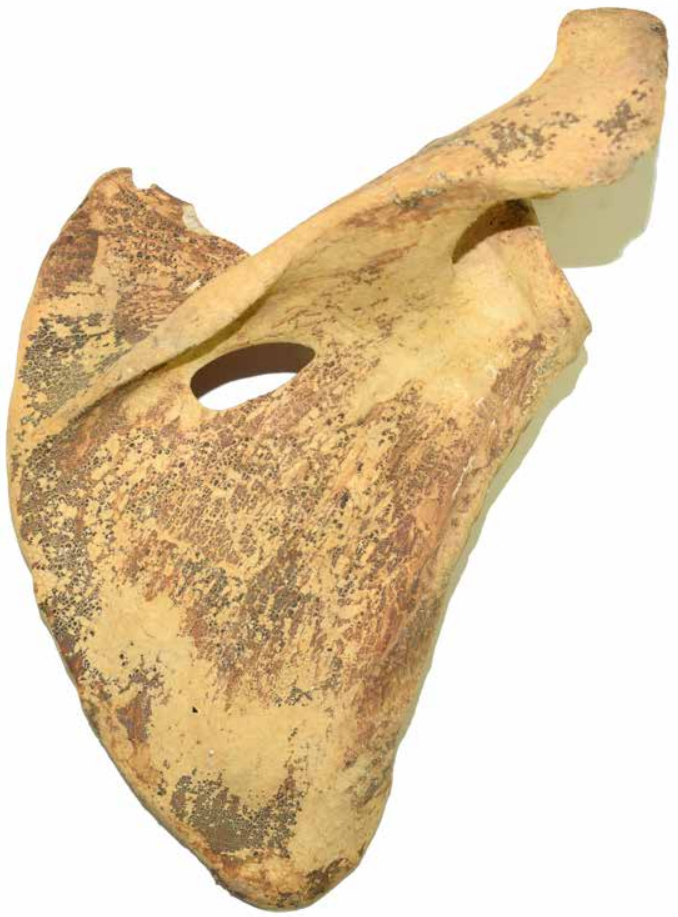

Pl. 4. Defect in ossification in right scapula, individual C265 (Photo: Gabriela Jungová). 


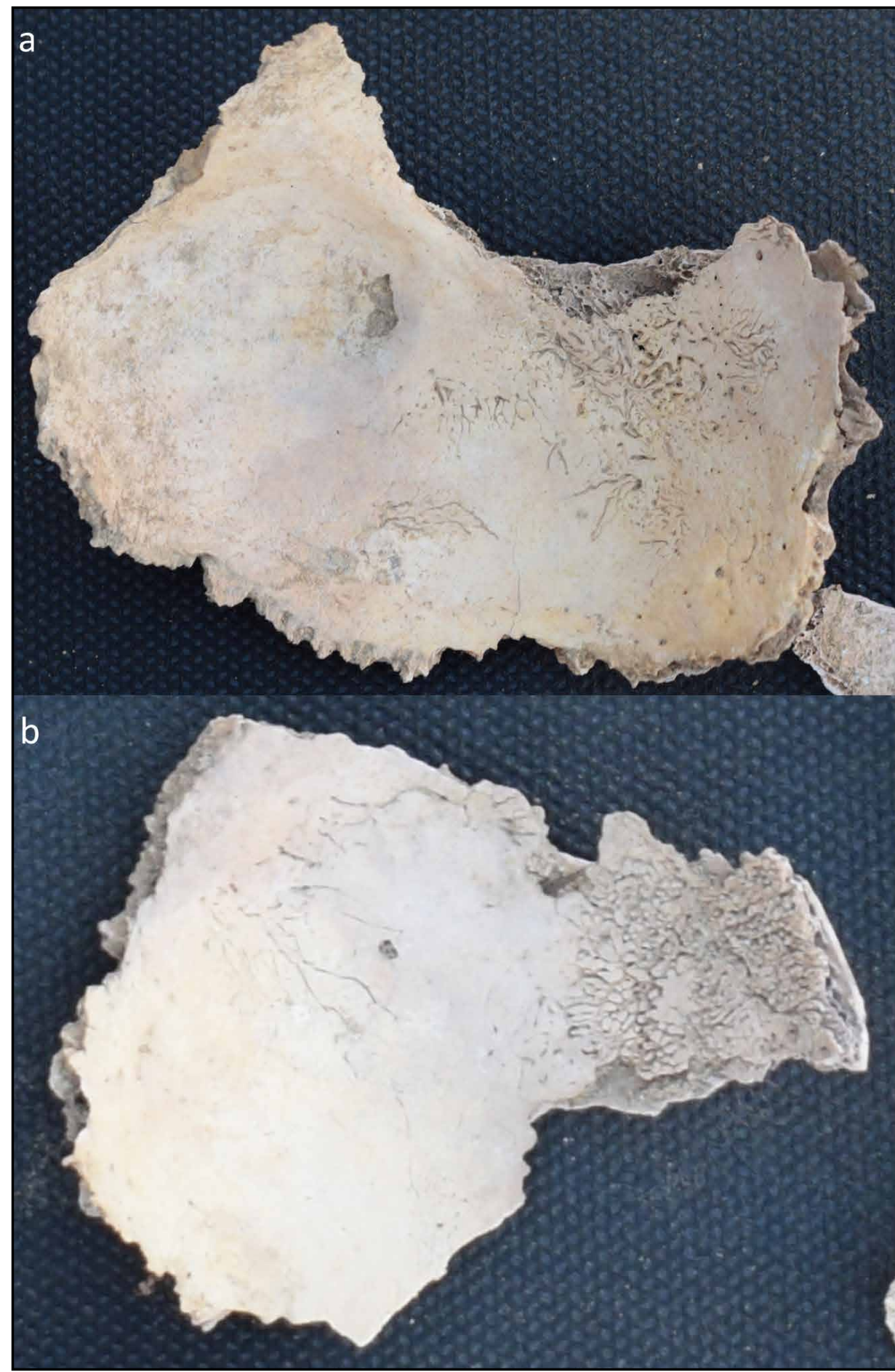

P1. 5. Endocranial lesions SES in individual C271 showing (a) typical maze-like branching and (b) hairon-end appearance (Photo: Gabriela Jungová). 